\title{
NEURILEMMOMA OF THE TONGUE
}

\author{
BY
}

\author{
R. D. P. CRAIG
}

From Wythenshawe Hospital, Manchester

(RECEIVED FOR PUBLICATION NOVEMBER 15, 1963)

Swellings of the tongue in children are usually of a haemangiomatous or lymphangiomatous type. Neurilemmoma of the tongue is a comparatively rare tumour at any age. Gnassi and Borrone (1938) reviewed 9 such cases, and since then 8 other cases have been reported. The case to be described is of interest because it represents the earliest age at which the condition has presented.

\section{Case Report}

A girl aged 8 attended as an out patient with a swelling of the right side of the tongue of one year's duration. It was first noticed by the mother when the child had a sore throat. It had gradually increased in size since that time.

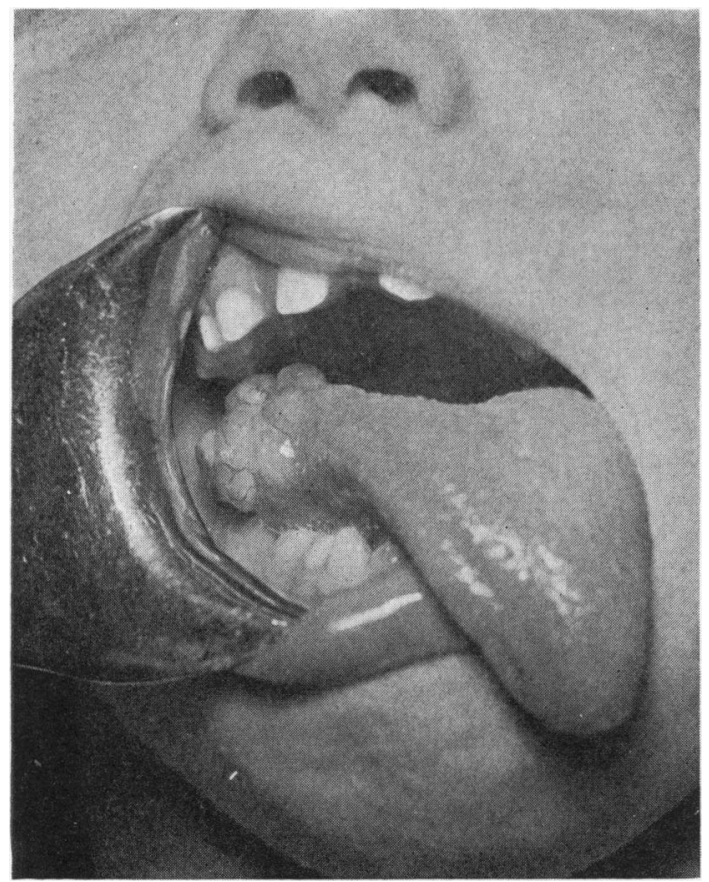

Fig. 1.-Showing swelling on lateral border of posterior third of tongue.
The patient had experienced no dysphasia or dysphagia.

On examination a firm nodular yellowish-white swelling measuring approximately $2.5 \times 2.0 \mathrm{~cm}$. was seen on the lateral border of the right side of the posterior third of the tongue. Intact mucous membrane covered its surface (Fig. 1).

In view of its position, radio-iodine uptake studies were done: these showed a normal uptake over the thyroid gland, but no special uptake over the swelling on the tongue.

A provisional diagnosis of ectopic salivary tumour was made.

At operation under general anaesthesia, a wellencapsulated tumour was easily freed from the surrounding tissues and the area thus created closed with two mattress sutures of braided silk.

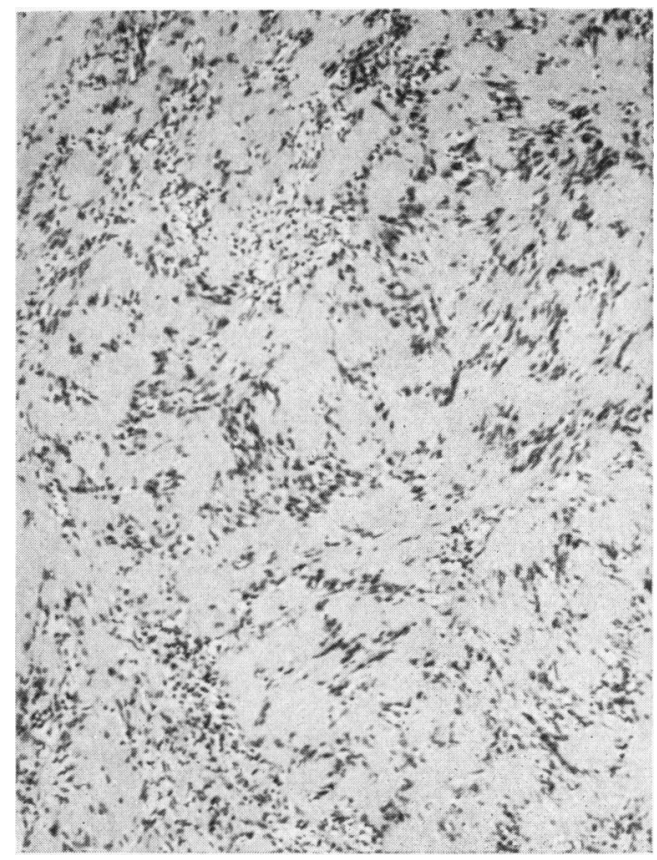

FIG. 2.-Photomicrograph $(\times 100)$, showing palisading of nuclei and bundles of collagen fibrils. 
Pathology. A portion of tissue measuring $3 \times 2 \times 1$ $\mathrm{cm}$. with an encapsulated mass of tumour tissue covered by squamous epithelium on one surface. The neoplasm was composed of orderly cells showing palisading of the nuclei separated by dense collagenized fibres (Fig. 2). There was no evidence of mitotic activity, and no cystic areas were present. The findings were those of a neurilemmoma of the tongue. There was no evidence of malignancy, and the lesion appeared to be completely excised.

\section{Discussion}

Neurilemmoma is usually a solitary tumour, though in a minority of cases it may be multiple and associated with Recklinghausen's disease. According to Willis (1953) it is slightly more common in women, and there is no significant variation with age.

Stones (1954) states that neurilemmoma of the oral cavity is extremely rare. It normally presents as a symptomless swelling noticed accidentally, but with increase in size it may occasionally give rise to symptoms of dysphasia or dysphagia. It may occur in any region of the tongue, but most frequently along the lateral border and tip (5 out of 9 in Gnassi and Borrone's series). This supports the theory of trauma occasionally preceding the appearance of the tumour as in the case described by Mercantini and Mopper (1959).

Differential diagnosis is from other benign swellings of the tongue including haemangioma, lymphangioma, ranula, dermoid cyst, teratoma, mucous cyst, thyroglossal cyst, rhabdomyoma, lipoma, fibroma, mixed salivary tumour and lingual thyroid. The last lies behind the foramen caecum at the base of the tongue, and is usually central in position, though sometimes lateral, according to Spencer (1914).

Histologically, the tumour consists of 'an interlacing network of wavy flowing streams of cells in which the nuclei palisade prominently'. This is known as Antoni Type A tissue (1920), while Type B shows no orientation of cells, but with microcystic degeneration.

Opinion varies as to the exact origin of the tumour. Penfield and Young (1930) considered that it arose from the fibroblasts of the perineurium, whereas Masson (1932) believed that it arose from the Schwann cells of the neurolemmal sheath: this last view is supported by Willis (1953).

No cases of recurrence after excision have been reported.

\section{Summary}

A case of neurilemmoma of the tongue presenting in childhood is reported.

The aetiology, clinical presentation, differential diagnosis and management are discussed.

I should like to express my sincere gratitude to Mr. Randell Champion for his encouragement and permission to report this case; and to Dr. Kathleen Lodge for the pathological interpretations and the photomicrograph.

REFERENCES

Antoni, N. R. E. (1920). Über Ruckenmarkstumoren und Neurofibrome. Bergmann, Munich.

Gnassi, A. M. and Borrone, M. (1938). Schwannoma. Arch. Otolaryng., 27, 766.

Masson, P. (1932). Experimental and spontaneous schwannomas (peripheral gliomas). Amer. J. Path., 8, 367.

Mercantini, E. S. and Mopper, C. (1959). Neurilemmoma of the tongue. Arch. Derm., 79, 542.

Penfield, W. and Young, A. W. (1930). The nature of von Recklinghausen's disease and the tumors associated with it. Arch. Neurol. Psychiat. (Chic.), 23, 320.

Spencer, W. G. (1914). The thyreoglossal tract. Lancet, 1, 522 Stones, H. H. (1954). Oral and Dental Diseases, 3rd ed. Livingstone, Edinburgh.

Willis, R. A. (1953). Pathology of Tumours, 2nd ed. Butterworth, London. 